\title{
Metonymic Use of Senayan in Indonesian Political Discourse
}

\author{
Muhammad Adam ${ }^{1, *}$ Siti Hafsah ${ }^{2}$
}

\author{
${ }^{I}$ Faculty of Letters, Universitas Balikpapan \\ ${ }^{2}$ Faculty of Letters, Universitas Balikpapan \\ *Corresponding author. Email: adam@uniba-bpn.ac.id
}

\begin{abstract}
The use of metaphor and metonymy is pervasive in political discourse since it bridges the speaker/reader to its audience in delivering the message. This is also true in Indonesian political discourse, where various metonymies are used in political discourse, especially in media. This paper explores the use of Senayan in Indonesian Political Discourse to study what each use refers to and what it collocates with. For Indonesian native speakers, when reading or hearing the word in Indonesian political discourse, they will easily understand that Senayan refers in general to the House of Representatives and all associated with the institution. Senayan is the name of the local place in Jakarta where the building of the House of Representatives is located. This study aims to identify the exact referent of Senayan use as metonymy in political discourse. The study is qualitative and the data are headlines that are purposively taken from the Detiknews website. The result shows that the use of Senayan as metonymy does not only refer to an institution of the Indonesian House of Representatives but also can refer to the particular commission and particular member of the House of Representatives.
\end{abstract}

Keywords: Metonymy, Senayan, Political Discourse.

\section{INTRODUCTION}

White House in US Political Discourse is commonly used to refer to US Government as well as Downing Street in the UK to refer to British Prime Minister. Those are two examples of how place names are used as a metonymy of place to refer to an Institution. In the Indonesian political context, the use of Senayan is commonly used to refer to the House of Representatives or even an individual member of the institution. Senayan is the name of the place on which the building of the Indonesian House of Representatives (DPR), The People's Consultative Assembly (MPR), and Regional Representatives Council (DPD) are located. This study aims to examine the exact reference of the metonymic use of Senayan in several news articles and headlines.

The emergence of the conceptual approach or cognitive approach in metaphor and metonymy that was started from the work of Lakoff and Johnson [1] have brought many scholars to investigate the use of metaphor and metonymy in everyday discourse from a cognitive perspective. If a metaphor works in a crossmapping of one domain to another domain, metonymy is also similar in terms of mapping, but within the same and closer and related domain as asserted by Barcelona[2] who agrees that metonymy is a conceptual projection or mapping in a single, asymmetric mapping. Whereas Littlemore[3] defines metonymy as a cognitive and linguistics process in which we use one thing to refer to another. Lakoff and Johnson's [1] approach to classifying metonymy is to give more or less complex lists of its types, one of them is PLACE FOR INSTITUTION (e.g. The White House isn't saying anything.

Radden \& Kovecses [4] use the terms Idealized Cognitive Models (ICM) as the alternative terms for frame and image schema and assert that metonymy is a cognitive process in which one conceptual entity, the vehicle, provides mental access to another conceptual entity, the target, within the same idealized cognitive mode. The type of metonymy of Senayan is categorized into Location ICM which further elaborated by Littlemore [3] that PLACE FOR INSTITUTION is closely related to PLACE FOR INHABITANTS ICM. From the meaning construction process, Ruiz de Mendoza \& Mairal [5] provide a sketch which one of 
them as a place for an institution and people, as seen in figure 1 .

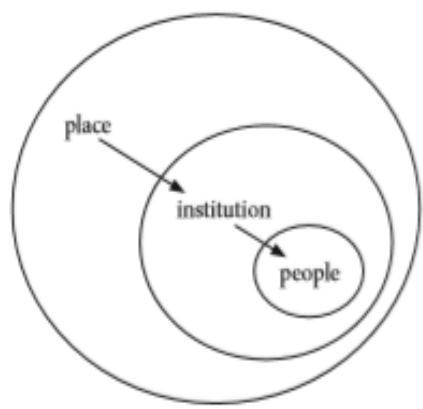

Figure 1 The diagram of PLACE for INSTITUTION metonymy

Where a name of the place is used to refer to an Institution within the place or building and also refers to the people that are members of the institution. There have been several studies in metonymy, some of them are by Halverson \& Engene, [6] who investigates the use of the place names Schengen and Maastricht in Norwegian newspaper corpora and concludes, whereas Guth [7] who measures the different editorial approaches Maryland area newspapers in the opening of the Chesapeake Bay Bridge in 1952 finds that Newspapers on both sides of the bay saw the bridge as a metonym for man's supremacy over nature. Adam (2019) who studies the use of Cendana in Indonesian media discourse reports that there are various referent of Cendana in the metonymic use that refers not only to the immediate family and is also used not only in political discourse.

\section{METHODOLOGY}

This research is qualitative descriptive, data from Detiknews online that contains the metonymic use of Senayan are purposively chosen. The stages of data collecting are: scanning the news from Detiknews that contains the word "Senayan". When Senayan is not referring to a place name, instead it is used in place of an institution or the related parts, it will be taken as the metonymic use. The collected data will then be displayed and categorized based on the institution and the exact referent of metonymic use of Senayan. After data collection and categorization, researchers analyze them to identify the reference of the metonymic use of those words, and how context also affects the referent and the collocation of metonymic use

\section{ANALYSIS}

The socio-historical and cultural context of a particular entity used as metonymy is very significant since to interpret the metonymy correctly, one must understand the source domain of the term used as metonymy and what characteristics relate it with the topic discussed. Figure 2 below is the summary of the metonymic use of Senayan, which was made by adapting the work of Ruiz De Mendoza and Mairal [5]

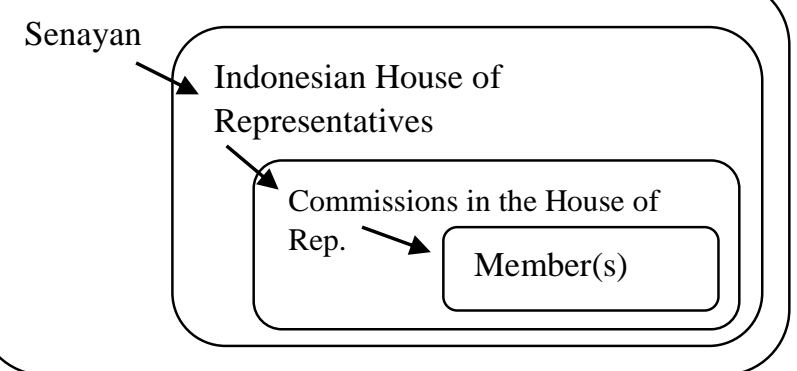

Figure 2 The Metonymic Use of Senayan

The use of Senayan as shown in figure 2, shows that the metonymic use is not only referred to an Institution as a single entity but also refers to the commission within the House of Representatives and the member of the institution. Eleven commissions in the House of Representatives cover each field in executive or government tasks. Furthermore, even that there are technically three institutions in the building in Senayan, i.e: the Indonesian House of Representatives (DPR), The People's Consultative Assembly (MPR), and Regional Representatives Council (DPD) but all metonymy refers to the House of Representatives.

\subsection{Senayan for The House of Representatives, for the Commissions within and the member}

The first referent of the metonymic use of Senayan is the institution, i.e: The House of Representatives. Approaching an election, most news headlines discuss the change of a party or the legislative candidate to be successful to secure a seat in the House of Representatives.

1). Hanura Terancam Tak Masuk Senayan, Wiranto Menolak Disalahkan [8]

Hanura may not go through Senayan, Wiranto refused to be blamed.

In data (1), It describes the possibility of a party, Hanura, not being able to place any of its candidates to the House of Representatives, and the comment on its ex-chairperson that is refused to be blamed on the situation.

2). Diprediksi Lolos ke Senayan, PKB Targetkan $15 \%$ Suara [9]

Predicted to go through Senayan, PKB targets 15\% votes

In data (2), one of the political parties describes its target of $15 \%$ vote in the election and is predicted to make it through Senayan. It means that the party will have their candidates of legislative members can have a chance to be a member of the House of Representatives. 
The use of Senayan as Metonymy, not only refers to the institution of House of Representatives but in several contexts, will also refer to particular commissions in the House, which have the counterpart from the Government or Executive side. There are eleven commissions with each scope in the Indonesian House of Representatives [10] each with its scope and duties.

In data 3, the headlines are about the consensus reached by all fractions of commission III with the scope of duties in Law and Legislation, Human Rights, and Security Affairs, to declare and accept the candidacy of new National Police Chief after fit and Proper test at the House of Representatives.

3). Satu Suara dari Senayan untuk Komjen Sigit Jadi Kapolri Baru [17]

One voice from Senayan for Komjen Sigit as New Chief of National Police.

Whereas in data (4), the use of Senayan refers to the members of Commission $\mathrm{X}$ with the scope of duties Education, Youth, Sport, Tourism, Arts and Culture Affairs that ask the Ministry of Education and Cultural Affairs to consider continuing the shut down for the school in light of the spreading of Covid-19.

4). Suara dari Senayan Minta Sekolah Tatap Muka Januari 2021 Ditunda [16]

The voice from Senayan to ask for the school opening in January to be cancelled

The metonymic use of Senayan in data (5) refers to members of the House of Representatives from various parties particularly from commission VI which covers Trade, Industrial, Investment, Cooperatives and Small and Medium Scale Enterprises, and State-Owned Enterprises Affairs. They raise their curiosity after statements made by minister Luhut Panjaitan who states one of the high officials of Pertamina, a state-owned oil company-, who is fired for not putting the local product as a priority in the company's supply. News journalists use Senayan to refer to those members

5). Tanda Tanya Senayan soal Sosok Pejabat Pertamina yang Dipecat Jokowi [15]

Senayan's question mark on the Pertamina official figures fired by Jokowi.

In data (6), the metonymic use of Senayan is referring to a particular member of the House of Representatives from commission IV (Agricultural, Plantations, Forestry, Maritime, Fisheries, and Food Affairs). They give an opinion to address the issue of ex-Minister of Indonesian fisheries Edhy Prabowo who was arrested by the Corruption Eradication Commission over gratification in the lobster export policy.

6). Sederet Pendapat Senayan Kala Menteri Edhy Prabowo Kena OTT KPK [11]
Some Senayan's opinion when Minister Edhy Prabowo caught red-handed by KPK

To be able to interpret and pinpoint the exact referent of the metonymic use of Senayan when it refers to a particular commission and member, one should read the full news to understand the context. Therefore, reading the metonymic use in isolation gives no possibility to acquire the full meaning or exact referent. unless the referent of Senayan is the institution The House of Representatives, then more possibility to interpret even without going through the whole news as can be understood from data (1) and data (2)

\subsection{The Collocation of Senayan Metonymy and the combination with metaphor}

When the use of Senayan around the election times, the collocation is whether a political party or a candidate will be successful to secure a seat in the House of Representatives. Thus, several uses as in (1) and (2) are examples of the metonymic use to describe the chance for a party or a candidate to secure a seat, or the opposite situation. Senayan is described as a political journey destination for parties during the election, and it is widely used as media headlines. Munro [12] agrees that headlines are a particularly powerful way in which key messages are conveyed to the reader, including those who do not go on to read the article in full or indepth, thus using metonymy and metaphor is a way to achieve that purpose.

The persuasive aspect in headlines is achieved not only by the single metonymy. As seen from (3), (4), and (5), that other metaphor are combined with Senayan metonymy. The use of:

\section{"satu suara dari Senayan" in (3) \\ One voice from Senayan \\ Suara dari Senayan in (4) \\ Voices from Senayan}

Tanda Tanya dari Senayan in (5), and Question mark from Senayan

Deliver a more persuasive sphere as there are other metaphors used in combination with metonymy. Suara or Voice in this particular context is used to refer to opinion and comment regarding each particular issue given by the member of the House of Representatives. Whereas tanda tanya or question mark is used as the metaphor for the number of questions regarding a particular issue. Pérez-Sobrino, Littlemore, \& Houghton [13] highlights that a combination of more than one metonymy or metaphor will surely bring a more persuasive impact.

The choice by the news author to choose the metonymic use of Senayan to refer to the House of 
Representatives as an institution, to the commissions within and the member(s) of House of Representatives is, of course, to achieve a persuasive impact as asserted Zashchitina [14] who studies the communicative aspect, stylistics and pragmatics of lexical tropes in mass media discourse and concludes that the cognitive aspect of tropes in modern non-literary discourse is not only an expressive means of the language but complex cognitive structures which can either affirm our schematic knowledge or bring substantial changes to it, and they can change the role that mass media audience take in interpreting texts thus giving mass media tropes a chance to influence and mould social practice

\section{CONCLUSION}

The metonymic use of Senayan in Indonesian political discourse in media extends not only to refer to the Institution but also can be specific to refer to the particular commissions and the member of the House of Representatives. The extensive use of Senayan as metonymy in Indonesian political discourse in media is possible since the socio-historical context embedded in the place name Senayan is the place where the building of The House of Representatives is located and has been widely known by Indonesian people. Furthermore, in media discourse particularly in political headlines, the metonymic use of Senayan not only provides a more expressive means but also to carry a more persuasive impact. Further studies should be conducted on a wider range of data and diachronically examine the extensive use of Senayan metonymy over time.

\section{AUTHORS' CONTRIBUTIONS}

The first author contributes to methodology, data collection and analysis, and Findings Section. The coauthor contributes to the introduction section, to find the relevant previous studies, and contributes to proofreading.

\section{ACKNOWLEDGMENTS}

We would like to extend high appreciation to the Faculty of Letters for their support during conducting the research.

\section{REFERENCES}

[1] Lakoff, G and Johnson, M. (1980). Metaphor We Live By. Chicago: University of Chicago Press.

[2] Barcelona, A. (2004). Names: A metonymic “ return ticket " in five languages. Jezikoslovlje, l(2003), 11-41.

[3] Littlemore, J. (2015). Metonymy: Hidden shortcuts in language, thought and communication. In Metonymy: Hidden Shortcuts in Language, Thought and Communication.
[4] Radden, G., \& Kovecses, Z. (2007). TOWARDS A THEORY OF METONYMY. In V. Evans, B. Bergen, \& J. Zinken (Eds.), The Cognitive Linguistics Reader (pp. 335-359). London: Equinox.

[5] Ruiz de Mendoza, F. J., \& Mairal, R. (2007). High-level metaphor and metonymy in meaning construction. Aspects of Meaning Construction, (June), 33-49.

[6] Halverson, S. L., \& Engene, J. O. (2010). Domains and dimensions in metonymy: A corpus-based study of Schengen and Maastricht. Metaphor and Symbol, 25(1), 1-18.

[7] Guth, D. W. (2008). The bay bridge metonymy: How maryland newspapers interpreted the opening of the Chesapeake bay bridge. American Journalism, 25(2), 57-83.

[8] DetikNews. (2019, April 26). Hanura Terancam Tak Masuk Senayan, Wiranto Menolak Disalahkan. Detik News. Retrieved from https://news.detik.com/berita/d-4526681/hanuraterancam-tak-masuk-senayan-wiranto-menolakdisalahkan

[9] Astuti, N. A. R. (2019, April 4). Diprediksi Lolos ke Senayan, PKB Targetkan 15\% Suara. Detik News. Retrieved from https://news.detik.com/berita/d4497213/diprediksi-lolos-ke-senayan-pkbtargetkan-15-suara

[10] Sekretariat Jenderal DPR RI. (2015). THE HOUSE OF REPRESENTATIVES OF THE REPUBLIC OF INDONESIA - COMMISSIONS. Retrieved March 12, 2021, from

[11] Dharmastuti, H. (2020, November 25). Sederet Pendapat Senayan Kala Menteri Edhy Prabowo Kena OTT KPK. Detik News. Retrieved from https://news.detik.com/berita/d-5270025/sederetpendapat-senayan-kala-menteri-edhy-prabowokena-ott-kpk

[12] Munro, M. (2018). Munro , M . ( 2018 ) House price inflation in the news: a critical discourse analysis of newspaper coverage in the UK. Housing Studies , 33 (7). 33 (January), 1085-1105.

[13] Pérez-Sobrino, P., Littlemore, J., \& Houghton, D. (2019). The Role of Figurative Complexity in the Comprehension and Appreciation of Advertisements. Applied Linguistics, 40(6), 957991.

[14]Zashchitina, G. (2014). Communication Mediators: The Cognitive and Pragma-stylistic Aspect of 
Tropes in Modern Mass Media Discourse. RUDN Journal of Philoshopy, 1, 32-39.

[15] DetikNews. (2021b, March 11). Tanda Tanya Senayan soal Sosok Pejabat Pertamina yang Dipecat Jokowi. Detik News. Retrieved from https://news.detik.com/berita/d-5489223/tandatanya-senayan-soal-sosok-pejabat-pertamina-yangdipecat-jokowi

[16] DetikNews. (2020, December 25). Suara dari Senayan Minta Sekolah Tatap Muka Januari 2021 Ditunda. Detik News. Retrieved from https://news.detik.com/berita/d-5308732/suaradari-senayan-minta-sekolah-tatap-muka-januari2021-ditunda

[17] DetikNews. (2021a, January 22). Satu Suara dari Senayan untuk Komjen Sigit Jadi Kapolri Baru. Detik News. Retrieved from https://news.detik.com/berita/d-5343839/satusuara-dari-senayan-untuk-komjen-sigit-jadikapolri-baru 